\title{
全球大気気候-波浪結合モデルによる 海面粗度を通した波浪の気候への影響評価
}

\author{
志村 智也 ${ }^{1}$ - 竹見 哲也 ${ }^{2} \cdot$ 森 信人 $^{3} \cdot$ 水田 亮 4 \\ ${ }^{1}$ 正会員 博 (工) 京都大学特定助教 防災研究所 ( \\ E-mail: shimura.tomoya.2v@kyoto-u.ac.jp \\ ${ }^{2}$ 正会員 博 (理) 京都大学准教授 防災研究所 ( $\bar{T}$ 611-0011 京都府宇治市五ヶ庄) \\ 3 正会員 博 (工) 京都大学准教授 防災研究所 ( 7 611-0011 京都府宇治市五ヶ庄) \\ 4非会員博 (理) 気象庁気象研究所主任研究官気候研究部 (テ 305-0052 茨城県つくば市長峰 1-1)
}

\begin{abstract}
波浪は気候システム内で大気海洋間の相互作用を通して重要な役割を担う素過程である.本研究では, 全球大気 気候モデルとスペクトル波浪モデルを用い, 波浪依存の海面粗度を考慮した気候計算を行った。海面粗度に波 形勾配および波齢に依存した 2 種類の式を用いて感度解析を行った結果, 海面粗度 (抵抗係数) 気候值は, 波 形勾配を用いた場合にはうねりの卓越度合に応じた，波龄を用いた場合には風向の定常性に心じた空間分布を とる. 光の海面粗度気候値の違いに伴い, 波浪を考慮しない計算に比へて, 海上風速気候値に $1 \mathrm{~m} / \mathrm{s}$ 程度の差が 生じ，特に低緯度て顕著で，15\%程度の差となる.熱帯低気圧経路を例に挙げ，上層の気候値についても有意な 影響が及ぶことを示し，波浪結合の有無が気候モデルによる気候計算結果に広く影響することを明らかにした。
\end{abstract}

Key Words : wind waves, global climate model, GCM, coupled model, roughness

\section{1. 序 論}

地球温暖化に伴う気候変動の将来予測や特性の解明， さらに気候変動による影響評価か盛んに行われている1) 気候変動に関する研究は, 気候モデル (Global Climate Model: GCM) による気候シミュレーション結果に多く を依っており，実際の気候の物理過程を良く表現した 精緻な気候モデルが望まれる. 海岸工学分野において も GCM の計算にもとづき，気候変動の海面上昇や波浪 への影響評価がなされている. 例えば， Shimura et al. ${ }^{2)}$ は，GCM の海上風を外力とし波浪モデルを駆動させ， 温暖化時の波候変化を評価している.

一方，波浪は気候システムから海上風を通して一方 向の影響を受けるだけでなく，気候システムに対する フィードバックか指摘されている ${ }^{3)}$. 大気海洋間におけ る運動量輸送，運動エネルギー輸送，熱輸送が波浪の 状態に依存することが観測されている．しかしながら， 既往の GCM の多くにおいて，波浪に依存した物理過 程は海上風速で表現されるか無視されている，例えば， 海面粗度は波形勾配や波齢などの波浪の状態に依存す ると仮定されているが4),5), 風速の関数として単純に扱 われることがほとんどである . 波浪依存の海面粗度を 考慮した気候計算を行った研究が数例あるが 6),7),8), 気 候計算をするにとどまっており，気候に対する影響は 十分に明らかにされていない. 弚こで本研究では, 大 気 GCM と波浪モデルを結合して，波浪を考慮した気
候計算を行い，気候システムに対する波浪の影響を評 価することを目的とする .

\section{2. モデル概要・実験設定概要}

\section{(1) GCM}

気象庁気象研究所で開発された全球大気気候モデル である MRI-AGCM ${ }^{9)}$ を用いた . MRI-AGCM の気候計 算結果にもとづき, 台風 ${ }^{10)}$ や高潮 ${ }^{11)}$, 波浪 ${ }^{2)}$ の気候変 動評価研究が行われている.モデル解像度はTL159L48 (水平 $1.125^{\circ}$, 鉛直 48 層) とした .

海面の運動量・熱フラックスは, 以下のバルク輸送 式で表される.

$$
\text { 運動量 : } u_{*}^{2}=C_{m} U^{2} \text {, 熱 : } u_{*} \theta_{*}=C_{h} U \triangle \theta
$$

ここで, $u_{*}$ は摩擦速度, $\theta_{*}$ は温度スケール, $U$ は海上風 速， $\Delta \theta$ は海上大気温度と海面温度の差, $C_{m}$ は運動量 輸送係数 (抵抗係数) , $C_{h}$ は熱輸送係数である. $C_{m}, C_{h}$ は, Monin-Obukhov の相似則 ${ }^{12)}$ にもとづき以下のよう に表される .

$$
\begin{gathered}
C_{m}=\frac{\kappa^{2}}{\left[\log \left(\frac{z}{z_{0 m}}\right)-\psi_{m}\left(\frac{z}{L}\right)\right]^{2}} \\
C_{h}=\frac{\kappa^{2}}{\left[\log \left(\frac{z}{z_{0 m}}\right)-\psi_{m}\left(\frac{z}{L}\right)\right]\left[\log \left(\frac{z}{z_{0 h}}\right)-\psi_{h}\left(\frac{z}{L}\right)\right]}
\end{gathered}
$$

ここで, $\kappa$ はカルマン定数 $(=0.4), L$ は Monin-Obukhov 長, $z$ は高度, $\psi_{m} \psi_{h}$ は密度成層による対数則からの 


\begin{tabular}{l|c|c|c|c}
\hline 実験名 & 波浪結合有無 & 海面粗度の式 & 計算期間 (初期値) & 水平解像度 GCM/波浪モデル \\
\hline CHA02 & 無 & $\alpha=0.02$ & $1990-2014(2 \mathrm{run})$ & $1.125^{\circ} /-$ \\
\hline CHA001 & 無 & $\alpha=0.01$ & $1990-2014(2 \mathrm{run})$ & $1.125^{\circ} /-$ \\
\hline TY2001 & 有 & Taylor and Yelland (2001) & $1990-2014(2 \mathrm{run})$ & $1.125^{\circ} / 1.25^{\circ}$ \\
\hline DR2003 & 有 & Drennan et al. (2003) & $1990-2014(2 \mathrm{run})$ & $1.125^{\circ} / 1.125^{\circ}$ \\
\hline
\end{tabular}

ずれを表す関数, $z_{0 m}, z_{0 h}$ は運動量および熱に関する粗 度長である. 運動量に対する粗度長は，

$$
z_{0 m}=0.11 \frac{\nu}{u_{*}}+\alpha \frac{u_{*}^{2}}{g}
$$

で表される . 右辺第 1 項において $\nu$ は空気の動粘性係 数であり, 低風速時で海面が滑らかな状態の粗度を表 す . 右辺第 2 項は，海面が滑らかではない状態 (波浪) の粗度であり，Charnock ${ }^{13)}$ の式により表されている Charnock $^{13)}$ は Charnock 係数 $\alpha=0.018$ を提案してい

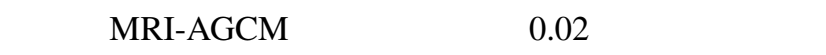
増加するにつれ粗度が増加し, 海面の状態 (波浪)を単 純に風速によって表現している．熱に対する粗度長は， 波浪の影響は考慮されず， $z_{0 h}=0.62 \nu / u_{*}$ で表される.

\section{（2）波浪モデル}

波浪モデルには，NOAA のスペクトル波浪モデル WAVEWATCH III ver.4.18 ${ }^{14)}$ を用いた。計算ドメイン は全球 $78^{\circ} \mathrm{S}-75^{\circ} \mathrm{N}$, 水平解像度は $1.125^{\circ}$ もしくは $1.25^{\circ}$ とした . 周波数解像度は 0.035 から $0.56 \mathrm{~Hz}$ を対数的に 30 分割し, 方向解像度は $10^{\circ}$ とした .ソース項(風によ る発達および散逸)には Ardhuin et al. ${ }^{15)}$ のパラメタリ ゼーションを用い, 非線形相互作用は DIA で計算する。

\section{(3) 波浪依存の海面粗度}

Taylor and Yelland ${ }^{4)}$ は, $z_{0 m}$ を波形勾配の関数とした 以下の式を提案している .

$$
\frac{z_{0 m}}{H_{s}}=A_{1}\left(\frac{H_{s}}{L_{p}}\right)^{B_{1}}
$$

$H_{s}$ は有義波高， $L_{p}$ はピーク波長， $A_{1}$ と $B_{1}$ は係数で あり, オランダ沖 , バルチック海 , オンタリオ湖におけ る観測をもとに $A_{1}=1200, B_{1}=4.5$ と決定している．

Drennan et al. (2003) は， $z_{0 m}$ を波齢の関数とした以 下の式を提案している.

$$
\frac{z_{0 m}}{H_{s}}=A_{2}\left(\frac{u_{*}}{c_{p}}\right)^{B_{2}}
$$

ここで, $c_{p}$ は風波成分のピーク波速である.地中海，才 ンタリオ湖 , 米ヴァージニア沖 , 北海における観測を もとに $A_{2}=3.35, B_{2}=3.4$ と決定している.

上記の式のスペクトルピークの定義は，波形勾配の 式がスペクトル全体のピークであり, 波龄の式は風波 成分のピークである. Drennan et al. ${ }^{16)}$ は, 上記の波形勾 配と波齢に依存した粗度の式の適用性を樣々な観測値
をもとに検討している . 結論として , 風速のみで $C_{m}$ を 表現した式に比べ上記の式は観測と合うとし，うねり と風波が混在する“mixed sea”では波形勾配の式が，風 波が発達中の “young sea”では波齢の式がより観測值と 整合性があるとしている .

ここで，海面粗度の式の違いを明確にするために， Charnock の式と同樣な形に変形する . 深海条件と分散 関係式および平衡状態の風波の関係式 (鳥羽 $3 / 2$ 乗則),

$$
\frac{g H_{s}^{e q}}{u_{*}^{2}}=\alpha_{T}\left(\frac{g T_{s}^{e q}}{u_{*}}\right)^{3 / 2}
$$

を用いる. $\alpha_{T}=0.062$ であり，風波成分に対して式 (7) は常に成り立つとする.また, $T_{p}^{e q}=C_{t} T_{s}^{e q}, H_{s}=$ $a_{h} H_{s}^{e q}, L_{p}=a_{l} L_{p}^{e q}$ とする $. a_{h}, a_{l}$ は波浪の風波からの ずれ(うねりの混在)を表す値とする.結果，式(5)は，

$$
\begin{aligned}
& z_{0 m}= \\
& A_{1}(2 \pi)^{\frac{B_{1}+3}{2}} C_{t}^{\frac{3(B 1+1)}{2}} \alpha_{T}^{B_{1}+1} \frac{a_{h}^{B_{1}+1}}{a_{l}^{B_{1}}}\left(\frac{u_{*}}{c_{p}^{e q}}\right)^{\frac{B_{1}-3}{2}} \cdot \frac{u_{*}^{2}}{g} \\
& =\alpha_{T Y 2001} \cdot \frac{u_{*}^{2}}{g}
\end{aligned}
$$

となり，式(5)における Charnock 係数 $\left(\alpha_{T Y 2001}\right)$ が, 波浪の風波からのずれ $\left(a_{h}^{B_{1}+1} / a_{l}^{B_{1}}\right)$ および波齢の逆数 $\left(u_{*} / c_{p}^{e q}\right)$ で表される . 係数の值を代入すると $\left(C_{t}=0.95\right)$,

$$
\alpha_{T Y 2001}=0.18 \frac{a_{h}^{5.5}}{a_{l}^{4.5}}\left(\frac{u_{*}}{c_{p}^{e q}}\right)^{0.75}
$$

となる.一方で式 (6) は，

$$
\begin{array}{r}
z_{0 m}=A_{2}(2 \pi)^{3 / 2} C_{t}^{3 / 2} \alpha_{T} a_{h}\left(\frac{u_{*}}{c_{p}^{e q}}\right)^{B_{2}-3 / 2} \cdot \frac{u_{*}^{2}}{g} \\
=\alpha_{D R 2003} \cdot \frac{u_{*}^{2}}{g}
\end{array}
$$

であり(ここで $\left.c_{p}=c_{p}^{e q}\right)$ ，係数の值を代入すると，

$$
\alpha_{D R 2003}=3.03 a_{h}\left(\frac{u_{*}}{c_{p}^{e q}}\right)^{1.9}
$$

となる.式 (9) と式(11) を比較すると，ともに波齢が 大きくなると Charnock 係数が小さくなるが, 式 (9) は 風波からのずれの影響が強く, 式 (11) は波齡の影響が 強いことが分かる $. a_{h}, a_{l}=1$ として Charnock 係数が

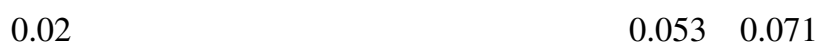
のときである .

\section{(4) 実験設定概要}

風速のみで表現した粗度および波浪依存の粗度を用 いた気候計算を光れ光れ行う。気候計算は，HadISST ${ }^{17)}$ 
の海水面温度と海水を境界条件として 1990-2014 年の 25 年間を行う．ただし，初期值を変えて光れ光れ 2 回 計算を行うため 50 年分のデータとなる . 風速のみで表 現した粗度の計算は, Charnock 係数 $\alpha=0.02$ および 0.01 を用いる . また，上記の波形勾配に依存した式 ${ }^{4)}$ と波齢に依存した式 ${ }^{5)}$ にもとづき，MRI-AGCM から 風速を，WAVEWATCH III からは粗度を交換して結合 計算を実施した .モデル間の変数交換間隔は 1 時間で

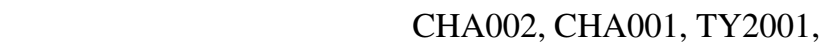
DR2003 として，実験概要を表-1にまとめた .

\section{3. 結果}

\section{(1) 海上風速と抵抗係数 $\left(C_{m}\right)$ の関係}

海上風速 $\left(10 \mathrm{~m}\right.$ 高度風速: $\left.U_{10}\right)$ と抵抗係数 $\left(C_{m}\right)$ の関係 が , 波浪依存の海面粗度を導入したことにより，どのよ うに変化するか示す. 図-1に, 北太平洋中高緯度 $\left(40^{\circ} \mathrm{N}-\right.$ $\left.50^{\circ} \mathrm{N}, 140^{\circ} \mathrm{W}-180^{\circ} \mathrm{W}\right)$ および太平洋赤道付近 $\left(5^{\circ} \mathrm{S}-5^{\circ} \mathrm{N}\right.$, $\left.140^{\circ} \mathrm{W}-180^{\circ} \mathrm{W}\right)$ における関係を例として示す .ここで， $C_{m}$ は中立条件のときのものである . 表-1の 4 つの実験 以外に参考值として , ヨーロッパ中期気象予報センター (ECMWF) の再解析值である ERA-Interim ${ }^{18)}$ の結果を付 記している，ECMWF モデルは，他の機関に先駆けて 大気モデルと波浪モデルを結合し，実務的に運用されて いる.ECMWF のモデルにおいて波浪依存の海面粗度 (Charnock 係数) は Janssen ${ }^{19)}$ にもとづき表現している 図-1には,さらに, the Coupled Ocean-Atmosphere Response Experiment 3.0 (COARE3) bulk flux algorithm ${ }^{20)}$ による $U_{10}$ のみで $C_{m}$ を表現した式も付記している

波浪を考慮しない実験では，当然， $U_{10}$ に対する $C_{m}$ はほとんど一意に決まる，一方で, 波浪依存の粗度を 用いた実験 (TY2001,DR2003) では同じ風速でも波浪の 状態に依って大きなばらつきがある．平均的には，北 太平洋中高緯度においては (図-1(a)), TY2001 は低風速 でCHA001に近く，風速か増すにつれて CHA002に近 づく.これは, 最近の観測にもとづいて提案されてい る式 (COARE3) に近い傾向である . DR2003では， $C_{m}$ が低風速で CHA001 より小さく，高風速でCHA002 よ り大きくなる .これは, 式 (11) が示すように波齢の逆 数に鋭敏なためである.波浪の状態の気候值が海域に よって変化するため, 上記の関係には海域依存性がある 図-1(b) に太平洋赤道域における関係を示す．TY2001， DR2003 ともにCHA001 より大幅に $C_{m}$ が小さくなる 図-1(a) と (b) の間で, 特に TY2001 で傾向が変わるの は，TY2001 は式(9)に示す通り風波からのずれに鋭敏 であり，低緯度でうねりが卓越し波形勾配がより小さ く表現されるためである.DR2003は風波成分の波齢を 使うためうねりの影響は小さい . ERA-Interimにおいて は $20 \mathrm{~m} / \mathrm{s}$ 程度までの風速域で, $C_{m}$ は CHA002 より小
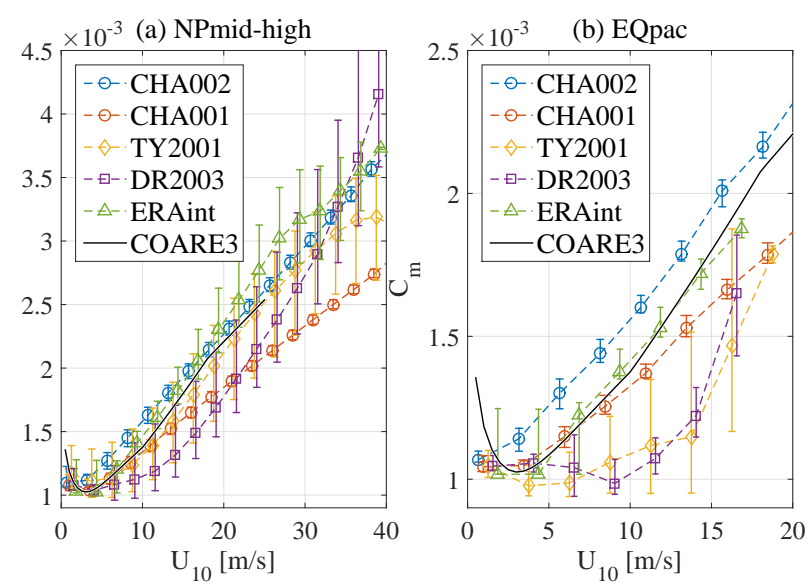

図-1 $U_{10}$ と $C_{m}$ の関係 . (a) 北太平洋中高緯度 . (b) 太平洋赤 道付近 . エラーバーは標準偏差を表す。

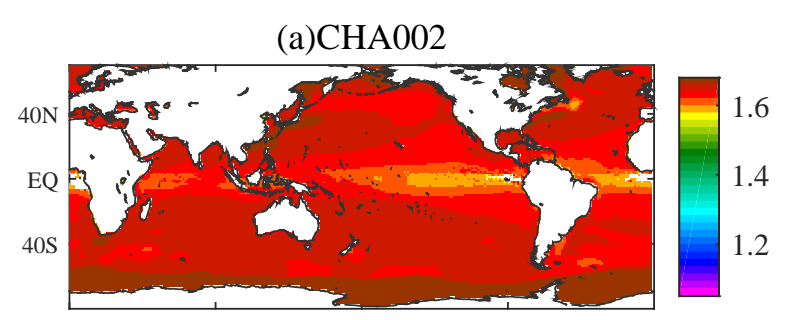

(b)TY2001

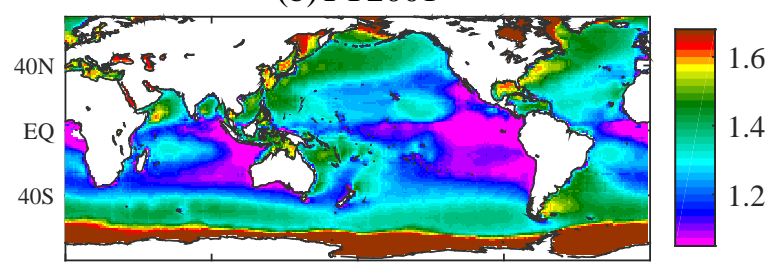

(c)DR2003



(d)ERAinterim

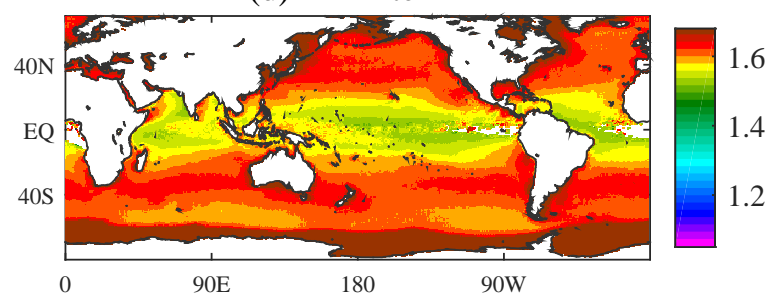

図-2 $C_{m}$ 気候値 $(\times 1000)$ の空間分布 . $U_{10}$ が $10 \sim 10.25 \mathrm{~m} / \mathrm{s}$ のときの平均值を表す. (a)CHA002， (b)TY2001， (c)DR2003, (d)ERA-Interim.

さく，弚れ以降で大きくなる．また， $15 \mathrm{~m} / \mathrm{s}$ 程度までの 風速域では波浪状態による $C_{m}$ のばらつきは小さい．

$C_{m}$ の海域 (波浪状態の気候值) 依存性について示 す．図-2 は，CHA002, TY2001, DR2003 および ERAInterim 乥れ羿れにおける $U_{10}$ が 10〜 $10.25 \mathrm{~m} / \mathrm{s}$ におけ る $C_{m}$ の平均值である. 当然, CHA002においては, 風 速によって $C_{m}$ は一意に決まるので海域依存はほとん 
(a)CHA002

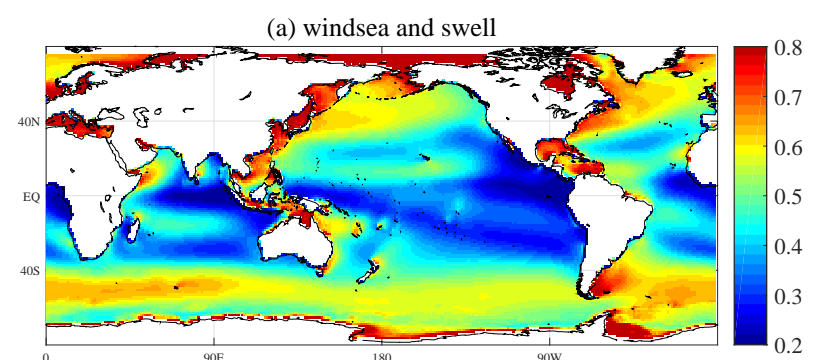

(b) only windsea

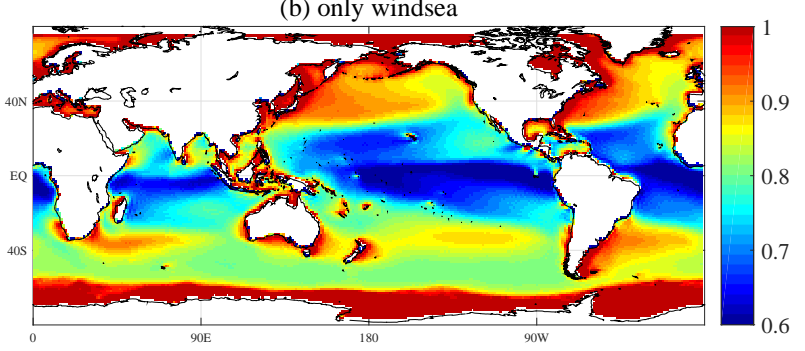

図-3 波齢の逆数 $\left(U_{10} / c_{p}\right)$ の気候值 . (a) 波浪スペクトル全体 のピーク波速，(b) 風波成分のピーク波速を用いる.

どない，TY2001 およびDR2003 では，明瞭な $C_{m}$ の 海域依存性を示す．TY2001では，低緯度および海洋東 側になるほど $C_{m}$ が小さくなる傾向にある .これはう ねりの卓越度合に対応している，一方で，DR2003で は, 低緯度で小さく, 中緯度 $\left(30 \sim 40^{\circ}\right.$ 付近) で極大とな る.これは, 低緯度は風向の変化が少なく波齡が大き くなりやすく，中緯度は風向のばらつきが大きく波齢 がさくなりやすいためである . ERA-Interim は , 海域 によるコントラストが小さいが，中緯度で極大になり DR2003 と空間的な傾向が類似している. ECMWF モ デルにおいて Charnock 係数は, 風による入力項のスペ クトル積分で表現されており風波成分で規定されるた め，風波成分で粗度を定義する DR2003 に空間的な傾 向が類似する.しかし, ECMWF モデルの粗度は海域 によるコントラストが小さい $U_{10}=10 \mathrm{~m} / \mathrm{s}$ かつ中立条 件において，吹送距離 $1 \mathrm{~km}$ および 100km の JONSWAP スペクトルを仮定すると， ECMWF モデル (Janssen ${ }^{19)}$ ) では, $C_{m}=1.45 \times 10^{-3}$ および $1.37 \times 10^{-3}$ である のに対して，DR2003では， $C_{m}=2.59 \times 10^{-3}$ および $1.30 \times 10^{-3}$ と幅が大きい .

TY2001 およびDR2003の $C_{m}$ の空間分布 (図-2) は， どちらも波齢の逆数 $\left(U_{10} / c_{p}\right)$ で説明できる . ただし， TY2001 では波速にスペクトルピーク，DR2003では風 波成分のスペクトルピークを用いる . 図-3 は TY2001 お

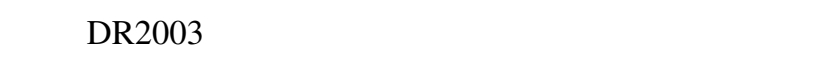
越度合および風向の定常性, さらに図-2 の空間分布と 良く対応している。これり，TY2001 およびDR2003 は光れ光れ粗度を波形勾配および波齢で定義している が，本質的には，スペクトルピークを用いるか，風波 成分のピークを用いるかということの違いが大きい .

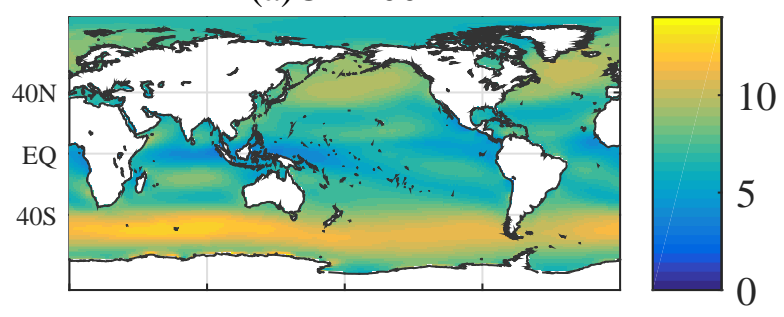

(b)CHA001

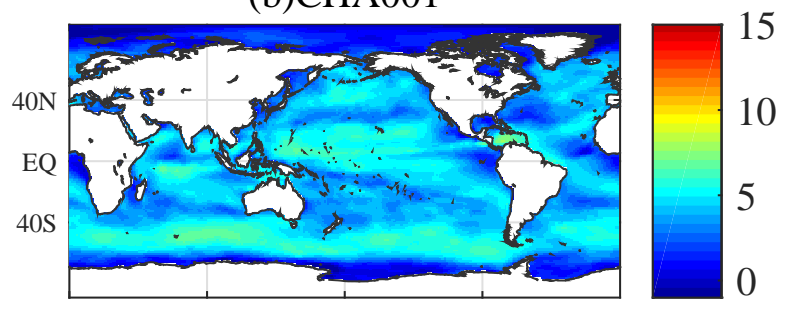

(c)TY2001

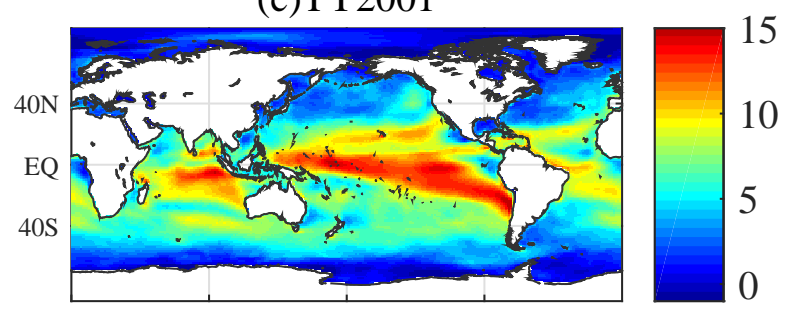

(d)DR2003

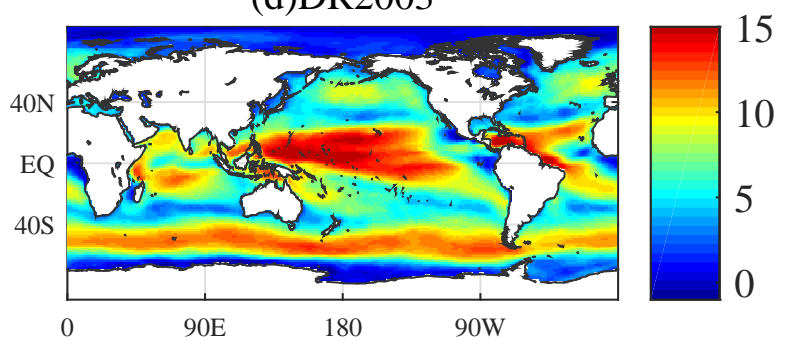

図-4 $U_{10}$ の気候値 . (a)CHA002 [m/s] . (b)〜 (d) は CHA001, TY2001, DR2003 の CHA002 からの差 [\%]

\section{(2) 気候值の差：U10}

前節に記述した海面粗度 (抵抗係数) の違いの海上風 速気候值に対する影響について示す．図-4は, CHA002 における $U_{10}$ 気候值と CHA001, TY2001 およびDR2003

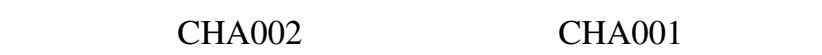
的に $5 \%$ 程度大きくなる．TY2001では低緯度で $15 \%$ 程 度大きくなり, 高緯度, 特に海洋西側でほとんど変わら なくなる.DR2003では，低緯度で，特に西側で 15\%程 度大きくなり，中緯度で差が小さくなり高緯度で $10 \%$ 程 度の差となる . これらの違いは, 明らかに図-2に示す $C_{m}$ および図-3に示す波齢の逆数の違いに対応してい る。つまり, 波浪の気候值に依存して海上風の気候值 に $15 \%, 1 \mathrm{~m} / \mathrm{s}$ 程度の違いが生じる。

それ光れの実験間の差を明確にするため, 図-5 に $U_{10}$ 気候值の帯状平均値を示す.参照値として， 衛星観測データをもとにして作成された複数の全 球海上風速格子点データを付記している.用いた データは, OAFlux ${ }^{21)}(1990-2014$ 年), NOAA Blended 


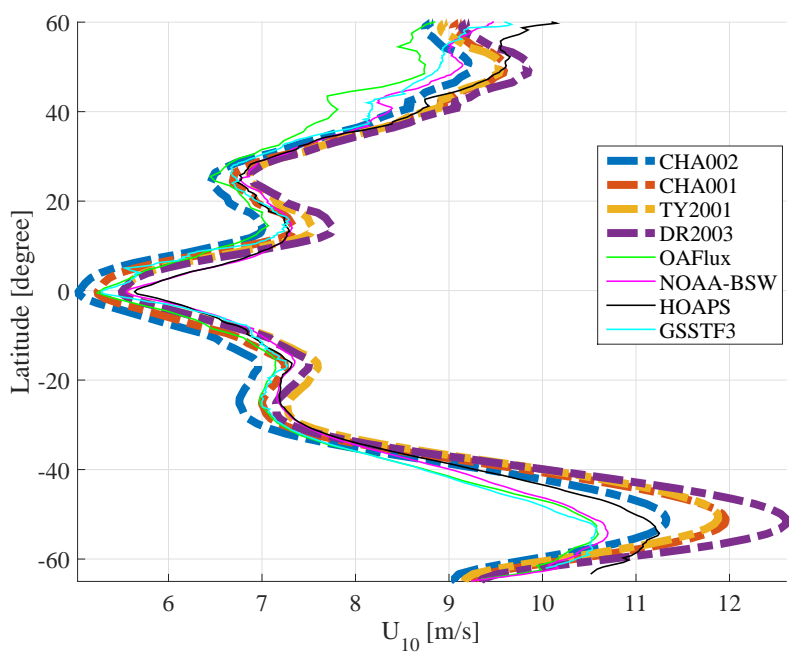

図-5 $U_{10}$ の気候値の帯状平均 . 太い波線は本研究の実験値で あり細い線は観測データを表す。
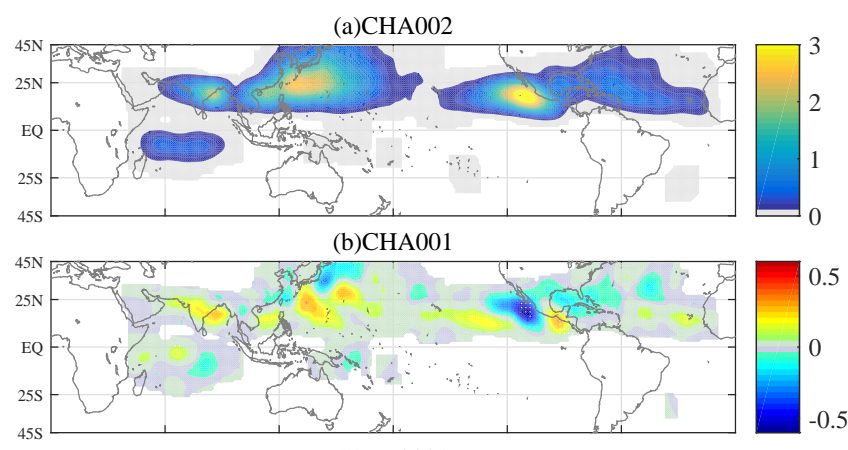

(c)TY2001
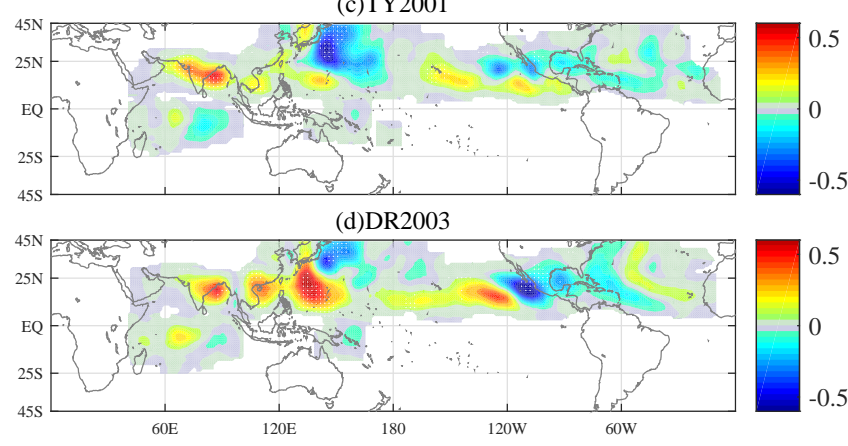

図-6 熱帯低気圧通過個数の気候值 (7-9 月)[個/年] . (a)CHA002 における気候値 . (b)〜 (d) は CHA001, TY2001, DR2003 乥れ染れの CHA002 からの差 . (b)〜 (d) の白点は 5\%水 準で差が有意な領域

Sea Winds ${ }^{22)}\left(1988-2010\right.$ 年), HOAPS ${ }^{23)}(1988-2008$ 年), GSSTF3 $^{24)}$ (1988-2008 年)である . 観測データ間にもば らつきはあるが，定性的には，本実験結果は中高緯度 (特に南水洋) で過大である．また，低緯度では実験間 のばらつきの範囲内に観測データが入り，中高緯度に 比へて TY2001, DR2003 が観測值に近くなる.

\section{(3) 気候值の差：熱帯低気圧}

抵抗係数や $U_{10}$ 気候值の実験間の違いを上に示した が, 弚れらは海面粗度のパラメタリゼーションを変化さ
せることで必然的に変化する部分である . 光れらの違い により，結果的にどのような気候值の変化が生じるか， 熱帯低気圧を例として示す. 熱帯低気圧は Murakami et al. ${ }^{10)}$ の方法により抽出した . 図-6 は，7・8・9 月にお ける CHA002 の熱帯低気圧通過個数気候値と CHA001,


である. 北西太平洋に注目すると，いずれの実験にお いても日本の東側で通過個数が減少し, 西側で増加す る.特に TY2001 および DR2003 においては差が大き $く, 0.5$ 個/年程度の統計的に有意な差がある. 以上の变 化は，熱帯低気圧経路が西側に寄ることを示しており， 北西太平洋 $\left(100^{\circ} \mathrm{E}-180^{\circ} \mathrm{E}, 0^{\circ} \mathrm{N}-45^{\circ} \mathrm{N}\right)$ て経路の重心は， CHA001, TY2001 およびDR2003 弚れ光れ CHA002 か ら 2.0,7.1, 4.4ㅇ西側にずれる.ここでは紙面の関係上， 降水量など光の他の気候値については割愛するが，光 れらについても有意な差が生じた .これらの変化は八 ドレー循環の緯度方向の縮小と対応していることが示 唆されたが詳細については今後の課題とする .

\section{4. 結論}

大気 GCM と波浪モデルを双方向結合し，大気－波 浪間の相互作用 (波浪依存の海面粗度) を考慮した気候 計算を行った。計算結果をもとに，大気 GCM 単独計算 と比較することにより波浪の大気気候に対する影響を 評価した . 海面粗度として波形勾配および波齢に依存 した 2 種類の式を用いたが, 海面粗度 (抵抗係数) 気 候値は乥れ光れ異なる空間分布となる.海面粗度（抵 抗係数) 気候值は，波形勾配を用いた場合はうねりの 卓越度合に応じて，中高緯度の西側で大きくなり低緯 度東側で小さくなる . 波齢を用いた場合は風向の定常 性 (吹送距離) に応じて, 中緯度で大きくなり低緯度西 側で小さくなる．弚れらの海面粗度気候値の違いによっ て, 波浪を考慮しない計算に比へて, 海上風速気候値 に $1 \mathrm{~m} / \mathrm{s}$ 程度の差が生じた.特に低緯度で波浪結合の有 無の差が大きく，波浪を考慮した計算は $15 \%$ 程度大き くなった .また，海面付近の気候値だけではなく，上層 の気候値についても有意な影響が及ぶことを，熱帯低 気圧通過個数を例に挙げ示した。

本研究では, 波浪依存の海面粗度に 2 種類の式を用 いて気候計算を行った．しかしながら，波浪依存の海 面粗度 (抵抗係数) については樣々な式が提案されて おり，最適なものについて合意に至っていない、気候計 算精度の向上のためには, 風速の強弱やうねりの卓越 度合 (図-3(a))，風波の波齢 (図-3(b)) の統計量 (気候值) が異なるいずれの海域でも適用できる精度の良い海面 粗度式が必要であり，弚の提案と光の式にもとづく気 候計算は今後の課題である. 
謝辞： 本研究は, 気象研究所および京都大学防災研 究所の共同研究の一環として行われ, 日本学術振興会 特別研究員奨励費と文部科学省気候変動リスク情報創 生プログラムのサポートによる成果である .ここに感 謝の意を評す。

\section{参考文献}

1) IPCC-AR5: Climate Change 2013: The Physical Science Basis, Cambridge Univ. Press, 2013.

2) Shimura, T., N. Mori and M.A. Hemer: Variability and future decreases in winter wave heights in the Western North Pacific, Geophys. Res. Lett., 43, 2716-2722, 2016.

3) Cavaleri, L., B. Fox-Kemper and M.A. Hemer: Wind waves in the coupled climate system, BAMS, 93, 1651-1661, 2012.

4) Taylor, P. K., and M. J. Yelland: The dependence of sea surface roughness on the height and steepness of the waves, J. Phys. Oceanogr., 31, 572-590, 2001.

5) Drennan, W. M., H. C. Graber, D. Hauser, and C. Quentin: On the wave age dependence of wind stress over pure wind seas, J. Geophys. Res., 108, 8062, 2003.

6) Janssen, P.A.E.M. and P. Viterbo: Ocean waves and the atmospheric climate, J. Clim., 9, 1269-1287, 1996.

7) Fan, Y., S.-J. Lin, I. M. Held, Z. Yu, and H. L. Tolman: Global ocean surface wave simulation using a coupled atmospherewave model, J. Clim., 25, 62336252, 2012.

8) Charles, E., and M.A. Hemer: Parameterization of a wavedependent surface roughness: A step towards a fully coupled atmosphere-ocean-sea ice-wave system, Proceedings of 13th International Workshop on Wave Hindcasting and Forecasting, 2013.

9) Mizuta, R., and Coauthors: Climate simulations using MRIAGCM3.2 with 20-km grid, J. Meteor. Soc. Japan, 90A, 233-258, 2012.

10) Murakami, H., R. Mizuta, and E. Shindo: Future changes in tropical cyclone activity projected by multi-physics and multi-SST ensemble experiments using the 60-km-mesh MRIAGCM. Clim. Dyn., 39, 2569-2584, 2012.

11) Yasuda, T., S. Nakajo, S. Kim, H. Mase, N. Mori and K. Horsburgh: Evaluation of future storm surge risk in East Asia based on state-of-the-art climate change projection, Coastal Engineering, 83, 65-71, 2014.

12) Monin, A.S., and A.M. Obukhov: Basic laws of turbulent mixing in the ground layer of the atmosphere, Akad. Nauk. SSSR Geofiz. Inst. Tr., 151, 163-187, 1954.
13) Charnock, H.: Wind stress on a water surface, Quart. J. Roy. Meteor. Soc., 81, 639-640, 1955.

14) Tolman, H.: User manual and system documentation of WAVEWATCH III version 4.18, NOAA/NWS/NCEP/MMAB Technical Note, 316, 2014.

15) Ardhuin, F., and Coauthors: Semiempirical dissipation source functions for ocean waves. Part I: Definition, calibration, and validation, J. Phys.Oceanogr., 40, 1917-1941, 2010.

16) Drennan, W.M., Taylor, P. K., and M. J. Yelland: Parameterizing the sea surface roughness, J. Phys.Oceanogr., 35, 835848, 2005.

17) Rayner, N., D. Parker, E. Horton, C. Folland, L. Alexander, D. Rowell, E. Kent, and A. Kaplan: Global analyses of sea surface temperature, sea ice, and night marine air temperature since the late nineteenth century, J. Geophys. Res., 108, 4407, 2003.

18) Dee, D.P. and Coauthors: The ERA-interim reanalysis: Configuration and performance of the data assimilation system, Quart. J. Roy. Meteor. Soc., 137, 553-597, 2011.

19) Janssen, P. A. E. M.: Quasi-linear theory of wind-wave generation applied to wave forecasting, J. Phys. Oceanogr., 21, 1631-1642, 1991.

20) Fairall, C. W., E. F. Bradley, J. E. Hare, A. A. Grachev, and J. B. Edson: Bulk parameterization of airsea fluxes: Updates and verification for the COARE algorithm, J. Clim., 16, 571-591, 2003.

21) Yu, L., X. Jin, and R. A. Weller: Multidecade global flux datasets from the Objectively Analyzed AirSea Fluxes (OAFlux) Project: Latent and sensible heat fluxes, ocean evaporation, and related surface meteorological variables, Woods Hole Oceanographic Institution OAFlux Project Tech. Rep. OA-2008-01, 64 pp, 2008.

22) Zhang, H. M., J. J. Bates, and R. W. Reynolds: Assessment of composite global sampling: Sea surface wind speed, Geophys. Res. Lett., 33, L17714, 2006.

23) K. Fennig, A. Andersson, S. Bakan, C. Klepp, and M. Schroeder: Hamburg Ocean Atmosphere Parameters and Fluxes from Satellite Data - HOAPS 3.2 Monthly Means 6-Hourly Composites, electronic publication, Satellite Application Facility on Climate Monitoring, doi:10.5676EUM_SAF_CMHOAPSV00, 2012.

24) Shie, C.-L., K. Hilburn, L. S. Chiu, R. Adler, I-I Lin, E. Nelkin, J. Ardizzone, and S. Gao: Goddard Satellite-Based Surface Turbulent Fluxes, Daily Grid, version 3, Greenbelt, MD, USA, Goddard Earth Science Data and Information Services Center (GES DISC), 2012.

(2016.3.16 受付)

\title{
OCEAN WAVE-DEPENDENT ROUGHNESS IMPACTS ON CLIMATE SYSTEM BY COUPLED ATMOSPHERIC GLOBAL CLIMATE-WAVE MODEL
}

\author{
Tomoya SHIMURA, Nobuhito MORI, Tetsuya TAKEMI and Ryo MIZUTA
}

\begin{abstract}
Ocean surface waves take important roles at an interface between atmosphere and ocean. The wave-dependent surface roughness was implemented into the Atmospheric Global Climate Model using the spectral wave model, and climate simulations were conducted. Wave steepness- and wave age-dependent roughness were considered. The spatial distributions of roughness climatology correspond to the dominance of swells for the climate simulation with wave steepnessdependent roughness and the stationarity of wind direction for that with wave age-dependent one, respectively. The differences of roughness cause the differences in surface wind climatology by $1 \mathrm{~m} / \mathrm{s}$ compared with uncoupled simulations, large differences especially at the lower-latitude. Furthermore, we indicate that the influences can extend to upper-atmosphere such as the climatology of tropical cyclone track. Implementing ocean waves into a climate model can have a wide impacts on the climate simulations.
\end{abstract}

